\title{
UDC 17.021.2:140.8
}

\author{
V. M. RUBSKYI ${ }^{*}$ \\ 1* Odessa National Maritime University (Odessa, Ukraine), e-mail pavv@te.net.ua, ORCID 0000-0003-3225-8287
}

\section{COMMUNICATION LEVELS OF THE INDIVIDUAL}

Purpose. The article deals with the problem of mutual perception of individuals, which implies the analysis of the anthropological prerequisites for the study of interpersonal communication. The work emphasizes the need to identify the gnoseological lacuna of the possibility and relevance of knowing someone else's "I". As well as the need to point out implicit metaphysical attitudes, universal for many worldviews, which are implicitly included in the theory of personal communication. Theoretical basis. The author proceeds from the logical consequences of the evolutionary premise in anthropology. He compares the psychophysical goals of the interpersonal communication task with its ideological theory, monitors the impossibility of the realizing the communication level declared in the consciousness. As an opposite evolutionary premise, the author cites the postulates of the "philosophy of dialogue" by F. Rosenzweig, F. Ebner, M. Buber, and others. The correlation of these philosophical positions reveals the inconsistency of materialistic reduction in anthropology. Originality. The author identifies four levels of communication: background, obstacle, function and dialogue. He represents the rationale for the fact that the first three levels do not need the existence of an individual "I". The first three levels leave the existential "I" unnecessary and therefore unclaimed. The philosophy of dialogue with the Other raises an equally important question about the conditions for the possibility of a metaphysical continuum in ontology, and in turn, suggests the acceptance of a philosophical premise about God as the space of subjectivity in the "I-You" dialogue. Conclusions. Philosophical understanding of the communication of two existential "I" demanded in communication is possible only within the framework of religious discourse. The phenomenal consciousness can enter into communication with a specific other phenomenal consciousness only when there is a metaphysical space between them, allowing for the possibility of communication of such a level. The materialistic conditioning by the human evolutionary needs in all its conceivable forms produces a reduction of the communicative inquiry, which makes the mutual perception of the two "I" impossible. In this psychophysiological anthropological model, there is no space for the possibility of a dialogue of individuals.

Keywords: "I"; personality; communication; worldview; metaphysics; Other; evolutionism

\section{Introduction}

As stated by T. V. Koshelskaya et al. (Koshelskaya, Muravyova, \& Mareeva, 2018), "the phenomenon of communication is the invariant that characterizes the most diverse approaches, theories and concepts in the field of modern anthropology (philosophical and psychological), so it should take center stage (or at least one of the central stages) in modern human sciences" (p. 85). If we proceed from the generally accepted evolutionary premise in anthropology, then everything perceived by man he perceives to the extent of his interest in survival and reproduction. The subject perceives another person, proceeding from the same instincts. This also includes the general characteristics of human cognitive abilities: distinguishing colors, smells, tones, etc.

This creates a situation in which the object "other person" is subconsciously decomposed into necessary, beneficial and disadvantageous parameters. Another person is perceived by the subject through the prism of his interest/non-interest in the qualities and abilities of the Other. Nevertheless, depending on the degree of convergence of the communication subjects, it becomes possible to choose the levels of mutual perception.

Publications and studies of recent years place an increasing emphasis on the evolutionary component of all psychophysical processes of general social and interpersonal communication. The most illustrative in this context is the collection of scientific articles "Virtue Ethics: Retro- 
spect and Perspect" edited by Elisa Grimi (2019). Matt Ridley’s (2016) brilliant book, "The Origins of Virtue", substantiates the biological reduction of all human acts down to the most "exalted" ones. The book "The Bonobo and the Atheist: in Search of Humanism Among the Primates" by Frans de Waal (2018) and a new article "Wisdom and the Origins of Moral Knowledge" by Randall Curren (2019) solve the same task, but somewhat from different view point. The authors can be reproached with implicit anthropomorphization of animals, but the results of their research are still the same: man does not go beyond the fundamental boundaries of the animal world. Finally, the resonant book of the famous American cognitive scientist Steven Pinker (2018) "Blank Sheet: the nature of man. Who and why refuses to recognize it today" summarizes the potentials of human nature, which can only be realized within the framework of biology and social constructionism.

We have good reason to believe that the mind is equipped with a set of emotions, motivations, ability to think and communicate, and that in any culture they obey the general logic. They are difficult to erase or radically change; they are formed by natural selection during the course of human evolution and owe their basic design (and some of its variations) to the information recorded in the genome. (Pinker, 2018, p. 99)

Pinker openly opposes the religious understanding of human consciousness. It is "only one of the networks in the brain systems" (Pinker, 2018, p. 61). The joint monograph "Institute of Human: Idea and Reality" edited by M. I. Frolova (2018) is devoted to the analysis of competing anthropological discourses. The article by I. I. Smirnov (2018) "Criticism of Metaphysics and the Postsecular Paradigm", in which the author problematizes the status of secular communication is devoted to the subject of competition of human models. Ulrika Carlsson in the article "Tragedy and Resentment" notes an important divarication in the measurement of social communication:

Indeed, a great deal of what matters to us in our relations with others is simply their attitudes and feelings toward us, and much of social life consists simply in the pursuit and communication of attitudes such as respect, approval, admiration, and love. The continental tradition seems to have gone the furthest in tracing the ethical significance of attitudes. (Carlsson, 2018, p. 1171)

However, neither these nor other scientific studies produce an actual measurement of the communication ontology and the conditions for their possibility. 


\section{Purpose}

The purpose of this study is to highlight the specific issues of mutual perception of individuals. This involves an analysis of the anthropological premises of interpersonal communication research. The work aims to demonstrate the impossibility of the highest form of interpersonal communication "I-You" in the framework of evolutionary anthropology. It is necessary to recognize implicit metaphysical attitudes that are universal for many worldviews, which make this form of communication possible.

\section{Statement of basic materials}

For the first level of human communication, the most characteristic parameter of the Other is the background. We perceive the most of people as a passive background, in the presence of which all events of our private and public life unfold. When we cross a crowded city, we most often do not pay attention to anyone specifically. Even if we pay attention, by the nature of the perception of the Other it is akin to the perception of statues, buildings and types, that is, inanimate objects. But if someday the city turned out to be deserted, then this absence would attract a lot of attention, since many people yet had a certain quality of perception, designated as "background". This level of perception does not require more than external parameters in a person.

The second level of communication is an obstacle. At this level, the perception of people as obstacles and objects that are obstacles is the same. Passers-by, poles, trees, etc., we bypass in the same way as obstacles to our path. If the other person, in contrast to material objects, occupies a psychological space, then not only the person as a physical object is taken into account, but also the aspects of his activity: you cannot make noise in the library; you should greet each other on meeting (as a marker of identification), etc. Interaction at this level serves security interests and partly social bearing.

The third level of communication is functional. The construction of relations between people most often remains only at the level of perception or rejection of its actions and functions. For example, communication with a teacher, sales assistant, police officer, etc. occurs at the level of one or another of their functions. The whole person (with his inner experiences, mental space, etc.) is not perceived in this construction of relations, but only the necessary parameter or function.

As a result, at this level of communication, the person with whom we interact can be completely replaced by another person (seller, police officer, etc.) without loss. Moreover, he can be replaced by a robot or a computer program that performs the same functions. Even now you can make purchases, pay for services or study without direct interaction with a living person. He is simply superfluous. For the vast majority of people, the rest of humanity is equally unnecessary, including their friends, love partners and even spouses. Christian cultural inertia represents friendship and love relationships in many ways as a sacred, metaphysical phenomenon. But during materialistic analysis, it is easy to make sure that a person does not and cannot have friends in the classical sense of the word. He is "friends" only with the functions he lacks: safety, approval, entertainment, etc.

You can conduct a mental experiment demonstrating the thesis: "You do not have friends, you are friends with functions". Imagine, you know for certain that one of your friends sincerely despises you, says bad things about you to common acquaintances, steals money from you, etc. Will he remain your friend after that? No! Thus, once a person changes his role (compensatory) 
function in relation to you, as he is already excluded from friends. This means that he personally, that is precisely he, as the corpuscle of an individual personality does not interest you. It only matters to you that he meets your needs. And your needs, in turn, are formed as forms of compensation for the missing elements of your psyche. As A. V. Saenko (2018) notes, the communication of subjects must and can overcome the philosophical "concepts" of G. Deleuze in the pursuit of the Other as such (p. 5). I. A. Inyushina (2017), following Mamardashvili, speaks of the need "to restore the vital impulses, restore what was said in philosophy behind a parade of theoretical concepts, clutches of the internal logic of the theoretical language itself", which cannot be reduced to a system of categories and terms. Using a computer analogy, I must say that the file "personality him/herself" as a rule is not requested by friends, colleagues or lovers. Only parameters that are lacking in the psyche as compensatory components are requested. Thus, in a physicalist and biological analysis, friendship with a person's personality is impossible for the reason that human perception is impossible. Only certain components of the psyche and somatics of some people, in which other people feel a certain need, are subject to perception.

The fourth level of communication is impossible if one cannot decide to introduce the metaphysical concepts of "soul" and "God". By soul, we mean a certain individual corpuscle of the "I" of the human person. That is, one who perceives his thinking in acts: "I think", "I do not feel", "I do not understand". In introspection not without difficulty, but we distinguish our "I" (ourselves) from our mental characteristics: abilities and inabilities. We also distinguish ourselves from our intelligence (IQ). This is especially evident in acts of joy in understanding something or awareness of the inability to understand something. Observing this in ourselves, we can assume that other people also have similar levels of self-awareness. However, this transference does not give us true knowledge, but rather projects our "I-concept" onto another. In the communication act only that which two subjects can output is perceived more or less qualitatively. The mental space of the interlocutor in many respects remains a "thing in itself". And while we can distinguish that in one case or another we have inadequately expressed our inner world and the quality of experiences, from our interlocutor we get only the "uttered thought" (F. I. Tiutchev) and some conventionally understood language of emotional expression.

Thus, in the framework of the materialistic-evolutionary approach, interpersonal communication is the communicating of the psychosomatic needs of one psyche with the corresponding parameters of another psyche in order to replenish the former. The matter is compounded by the fact that a more detailed analysis reveals that communication of request and satisfaction occurs within the same consciousness, i.e. it would be more correct to say that there is a relationship with the (present and missing) components of oneself, or else: self-satisfaction through the Other. One of M. K. Mamardashvili's later ideas is aimed at directing the singular "I" of an individual towards release from an endless circle of evolutionary consciousness (Rusakov, 2019, p. 48). The striving for the limit of the "fabric of society" according to this thought is what makes a person a full-fledged subject.

However, if we expect to enter into communication with the real corpuscle of human subjectivity ("soul"), which is impossible in the material-evolutionary universe, we must assume a continuum in which this is possible. This is the Kantian way of postulating God. If God has the ability to perceive man non-evolutionarily, non-adaptively, then only He can give a space for human interperception on the other side of mental and physical qualities. In this context, the existence of God appears as a practical space for communication, it is not only replenishes the missing part of 
its theory. This is a religious discourse of worldview, but only in it, or in one of its modes, it is permissible to believe that a complete perception of the Other is possible.

As for the evolutionary interaction with another person, it does not require his/her existence as a free mental individuality. The development of computer technology every year confirms this more and more. Today, successful development of interactive programs such as "Yandex Alisa" (https://alisayandeks.ru) or "Google Assistant" (https://assistant.google.com) is underway. So far, these programs are focused on more or less primitive dialogues, but in the options of "Alice" there is already the opportunity to talk on common philosophical and everyday topics. It is easy to agree with the optimism of the developers that for many people in the near future these computer applications can compensate or completely replace human communication. It would be more correct to put quotes around "human" as a sign of conventionality, since these applications, social networks, online games, etc. already clearly enough revealed the impersonality and pragmatism of almost all types of human interaction. Summarizing this idea as a whole, we can say that the development of electronic technologies of the 21st century has revealed the inhumanity of interpersonal communication.

Fundamental impossibility as a consequence of evolutionary unnecessity, lack of demand for a deep perception of another person is the common destiny of all communications, including the one with God. This level of communication will always be under suspicion of its reality and necessity. Satisfaction of the functional level of communication creates a situation in which most people have no reason to pose the question of personality deficit and motivation for its development and research. A "friend", giving a feeling of care, sheltering from loneliness, assisting in intellectual games, sharing or regulating emotional flows, turns out to be a quite sufficient interlocutor and life partner. In this regard, the film "Her" directed and written by Spike Jonze (Oscar 2013 for the best original screenplay) is indicative. The film takes place in the near future, the main character falls in love with his electronic interlocutor Samantha (operating system). In general, the plot does not seem unbelievable, if we assume the full functional and psychological satisfactoriness of such electronic applications in the future. Here it is appropriate to recall the person's highly developed ability to anthropomorphize and hypostatize communication objects: pets, favorite objects, etc.

Two directions in the philosophy and psychology of the twentieth century turned out to be sensitive to this issue: existentialism and poststructuralism. If the former seeks to single out the subject as singular and genuine, then the postmodernists followed the path of deconstructing the personality as a concept and as an ontology.

J. Lacan proposed the concept of a divisible human personality "divided". Consciousness appears in Lacan's philosophy as a fragmented heterogeneous "I", not identical to itself in selfperception. M. Foucault also thought in the same direction. He refuses the idea of personality in the ontological dimension and preaches "I-consciousness" as a variable, lasting discourse of communication with others. Foucault gives an understanding of identity not as an ontological givenness, but as a "practice of oneself", that is, a system of individual practices constituted through culture and society. In this space of communication, the postmodern individual is dispersed in speech communication as the functionality of his own discursive practices.

The "neo-tribalism" of the nomadology of G. Deleuze and F. Guattari postulates the same ontological decentralization. This is the fundamental premise of the postmodern theory of subjectivity. According to Deleuze and Guattari, symbolic tribes (nomads) are structures that facilitate the change in the linear perception of history and man to "polyphonic vitalism" (Saenko, 2018). 
The deterritorialization of Deleuze and Guattari includes a parallel multidirectional process within the human consciousness. In this dimension (schizoanalysis), the personality and worldview of each is formed by a social network of relationships, and we have no good reason to draw a line between inadequate and adequate consciousness. Indeed, in the original premise "Structures are a filter through which the entire personal experience and the formation of the personality as a whole" pass (Rusakov, 2019, p. 46). In a significant number of modern research, the postulate "I" is also questioned. One of the leading directions of modern cognitive science comes to the conclusion that the "I" is illusory and the mental dimension of consciousness is declared epiphenomenal (D. Swaab, D. Dennett, S. Harris, L. Wolpert and others).

The scientific crisis of anthropology, which L. S. Vygotsky wrote about at the beginning of the twentieth century, by the beginning of the twenty-first century, entered its new phase. As noted by V. I. Slobodchikov and E. I. Isayev (2000), «today we are on the verge of a paradigm shift in psychology, in the very type of scientificity of psychological knowledge, which should allow us to go beyond the "plane of ideas about ..."» (p. 132). This need to go beyond the locus of scientific and therapeutic efficiency arose on the one hand in connection with the development of holistic approaches to the study of personality. On the other hand, with the efficiency of epistemological anarchy in theories and practices of consciousness.

Closest to a metaphysical understanding of the mutual perception of "I" and the Other is the philosophy of dialogue, born and developed in the works of F. Rosenzweig, F. Ebner and M. Buber, M. M. Bakhtin and G. Marcel. It is characteristic that the social and religious in their philosophy become synonymous. Here the human "I" seeks and finds its genuine unique place. This is possible only before the equal "You" in a genuine relationship, which is only conceivable in the contact of two "I", not their output data. Hence, the "third-person speech" for M. Buber and M. M. Bakhtin becomes a metaphor for the lack of personality as in "I-It". The interlocutor in this Meeting is the very presence of the Other. He is not needed in order to get information, sympathy, help, clarification, etc. In this sense, "a person constitutes himself in opening to the Other. Other of a person is diverse ... in a specific human destiny, any opening can become constituent" (Koshelskaya, Muravyova, \& Mareeva, 2018, p. 82). S. S. Khoruzhii, which T. V. Koshelskaya et al. appeal to, distinguishes three types of Other. The most important of these is the "ontologically Other". It corresponds to the category of "God" in Christianity and is close to M. Heidegger's "Sein".

In the thoughts of Franz Rosenzweig about communication as a revelation, there is a powerful metaphysical premise that it is impossible to enter into communication outside the context of the presence of God. The objectification of everything that traditional religiosity contacts comes to life and is renewed in the dialogic nature of Martin Buber's philosophy. Ferdinand Ebner's "Pneumatic Fragments", contrasted with "religion" as a fixed form, turn out to be much more religious than the Gospels of miracles and healings. Dialogue with another person in F. Ebner is always a dialogue with God, because God of Ebner is not an abstract exaltation, but Jesus Christ embodied in everyday life.

A person who is not interested in the spiritual search for Another person dooms himself to being in the one-dimensional world "I-It", and in this perspective there is no reason to look for relationships with another "I" on the other side of ways to achieve evolutionary tasks. All forms of dialogue distortion reduce the search for the Other to a mirror that more or less reflects our expectations. Even moving away from the Christian maxim about love for the Other, you need to allow him to be really different in order to start a mirrorless dialogical relation- 
ship. According to S. A. Smirnov (2017) "such ultimate acceptance is possible only in personal communication with God" (p. 191).

\section{Originality}

The author has identified and described four relevant levels of communication: background, obstacle, function and dialogue. The study provides evidence that the first three levels leave the human "I" unnecessary and therefore unclaimed. In the framework of evolutionary anthropology, "dialogue with the Other" remains only an unrealizable speculative abstraction. At the same time, the philosophy of dialogue needs a theological continuum in anthropology or the acceptance of a philosophical premise about God as a space of subjectivity in the "I-You" dialogue.

\section{Conclusions}

As the analysis shows, a philosophical understanding of the communication of the two "I" is possible only in the situation of their relevance. In the framework of evolutionism, there is no space for the need for a concrete and unique "I" of the Other. It is possible only with the assumption of metaphysical premises or in religious discourse. Thus, the study of communicative parameters represents for each individual not always assumed freedom of choice of the perception level of the Other. In the first three types (background, obstacle, function) a deep "I" of the interlocutor is unnecessary. "Phenomenal consciousness" (P-consciousness), as defined by Ned Block is included in communication with another phenomenal consciousness only when there is a metaphysical assumption about the possibility of communication of such a level.

Prospects for further research may lie in the field of cognitive deviations of consciousness from adaptation tasks to the recognition of the irreducibility of human consciousness to the satisfaction of survival systems of the species.

\section{REFERENCES}

Carlsson, U. (2018). Tragedy and Resentment. Mind, 127(508), 1169-1191. doi: https://doi.org/10.1093/mind/fzx014 (in English)

Curren, R. (2019). Wisdom and the Origins of Moral Knowledge. In E. Grimi (Ed.), Virtue Ethics: Retrospect and Prospect (pp. 67-80). Springer. doi: https://doi.org/10.1007/978-3-030-15860-6_6 (in English)

Frolova, M. I. (Ed.). (2018). Institut cheloveka: Ideya i realnost. Moscow: LENAND. (in Russian)

Grimi, E. (Ed.). (2019). Virtue Ethics: Retrospect and Prospect. Springer. doi: https://doi.org/10.1007/978-3-03015860-6 (in English)

Inyushina, I. A. (2017). The formation of culture of philosophical thinking: M. K. Mamardashvili's ideas in the context of contemporary philosophical praxis. Philosophical Thought, 5, 62-67. doi: https://doi.org/ 10.7256/2409-8728.2017.5.22913 (in Russian)

Koshelskaya, T. V., Muravyova, O. I., \& Mareeva, L. V. (2018). Communication as a central phenomenon of contemporary anthropological concepts. Siberian Journal of Psychology, 67, 77-88. doi: https://doi.org/ 10.17223/17267080/67/6 (in Russian)

Pinker, S. (2018). Chistyy list. Priroda cheloveka. Kto i pochemu otkazyvaetsya priznavat ee segodnya. Moscow: Alpina non-fikshn. (in Russian)

Ridley, M. (2016). Proiskhozhdenie altruizma i dobrodeteli. Moscow: Eksmo. (in Russian)

Rusakov, S. S. (2019). Conceptual-categorical apparatus in social philosophy of M. K. Mamardashvili. Philosophical Thought, 1, 44-49. doi: https://doi.org/10.25136/2409-8728.2019.1.27477 (in Russian)

Saenko, A. V. (2018). Specificity of the notions of the language of philosophy according to G. Deleuze, F. Guattari and M. K. Mamardashvili. Philosophical Thought, 9, 1-10. doi: https://doi.org/10.25136/24098728.2018.9.27237 (in Russian) 
Slobodchikov, V. I., \& Isayev, Y. I. (2000). Osnovy psikhologicheskoy antropologii. Psikhologiya razvitiya cheloveka. Razvitie subektivnoy realnosti v ontogeneze. Moscow: Shkolnaya Pressa. (in Russian)

Smirnov, I. I. (2018). Criticism of metaphysics and post-secular paradigm. Philosophy and Culture, 8, 1-13. doi: https://doi.org/10.7256/2454-0757.2018.8.27106 (in Russian)

Smirnov, S. A. (2017). Antropologiya i psikhologiya: Vzglyad na cheloveka. Vstrechnyy vyzov. Mir psikhologii, 4(92), 185-197. (in Russian)

Waal, F. B. M. d. (2018). Moral bez relihii. V poshukakh liudskoho u prymativ. Kharkiv: Klub Simeinoho Dozvillia. (in Ukrainian)

\section{LIST OF REFERENCE LINKS}

Carlsson, U. Tragedy and Resentment / U. Carlsson // Mind. - 2018. - Vol. 127, Iss. 508. - P. 1169-1191. doi: https://doi.org/10.1093/mind/fzx014

Curren, R. Wisdom and the Origins of Moral Knowledge / R. Curren // Virtue Ethics: Retrospect and Prospect / ed. E. Grimi. - 2019. - P. 67-80. doi: https://doi.org/10.1007/978-3-030-15860-6_6

Институт человека: Идея и реальность / ред. М. И. Фролова. - Москва : ЛЕНАНД, 2018. - 348 с.

Virtue Ethics: Retrospect and Prospect / ed. E. Grimi. - Springer, 2019. - 207 p. doi: https://doi.org/10.1007/978-3030-15860-6

Инюшина, И. А. Формирование культуры философского мышления: идеи М. К. Мамардашвили в контексте современного философского праксиса / И. А. Инюшина // Философская мысль. - 2017. № 5. - C. 62-67. doi: https://doi.org/10.7256/2409-8728.2017.5.22913

Кошельская, Т. В. Коммуникация как центральный феномен современных антропологических концепций / Т. В. Кошельская, О. И. Муравьева, Л. В. Мареева // Сибирский психологический журнал. - 2018. № 67. - C. 77-88. doi: https://doi.org/10.17223/17267080/67/6

Пинкер, С. Чистый лист. Природа человека. Кто и почему отказывается признавать её сегодня / С. Пинкер. Москва : Альпина нон-фикшн, 2018. - 940 с.

Ридли, М. Происхождение альтруизма и добродетели / М. Ридли. - Москва : Эксмо, 2016. - 416 с.

Русаков, С. С. Понятийно-категориальный аппарат в социальной философии М. К. Мамардашвили / С. С. Русаков // Философская мысль. - 2019. - № 1. - С. 44-49. doi: https://doi.org/10.25136/24098728.2019.1.27477

Саенко, А. В. Специфика понятий языка философии по Ж. Делезу, Ф. Гваттари и М. К. Мамардашвили / А. В. Саенко // Философская мысль. - 2018. - № 9. - С. 1-10. doi: https://doi.org/10.25136/24098728.2018.9.27237

Слободчиков, В. И. Основы психологической антропологии. Психология развития человека. Развитие субъективной реальности в онтогенезе / В. И. Слободчиков, Е. И. Исаев. - Москва : Школьная Пресса, 2000. $-421 \mathrm{c}$.

Смирнов, И. И. Критика метафизики и постсекулярная парадигма / И. И. Смирнов // Философия и культура. - 2018. - № 8. - С. 1-13. doi: https://doi.org/10.7256/2454-0757.2018.8.27106

Смирнов, С. А. Антропология и психология: взгляд на человека. Встречный вызов / С. А. Смирнов // Мир психологии. - 2017. - № 4 (92). - С. 185-197.

де Вааль, Ф. Б. М. Мораль без релігії. В пошуках людського у приматів / Ф. Б. М. де Вааль. - Харків : Клуб Сімейного Дозвілля, 2018. - 272 с.

\section{В. М. РУБСЬКИЙ ${ }^{1^{*}}$}

1* Одеський національний морський університет (Одеса, Україна), ел. пошта pavv@te.net.ua, ORCID 0000-0003-3225-8287

\section{РІВНІ КОМУНІКАЦІЇ ОСОБИСТОСТІ}

Мета. У статті розглянута проблема взаємосприйняття особистостей, що передбачає аналіз антропологічних передумов дослідження міжособистісної комунікації. У роботі підкреслена необхідність виявлення гносеологічної лакуни можливості й затребуваності пізнання чужого "Я". А також вказати на імпліцитні метафізичні установки, універсальні для багатьох світоглядів, які імпліцитно включені в теорію спілкування особистостей. Теоретичний базис. Автор виходить з логічних наслідків еволюційної посилки в антрополо- 
гії. Зіставляє психофізичні цілі й завдання міжособистісної комунікації з ії ідеологічною теорією, відстежує неможливість реалізації заявленого в свідомості рівня комунікації. Як протилежну еволюційну посилку автор наводить постулати "філософії діалогу" Ф. Розенцвейга, Ф. Ебнера, М. Бубера та ін. Співвідношення цих філософських позицій виявляє неспроможність матеріалістичної редукції в антропології. Наукова новизна. Автор виділяє чотири рівні комунікації: фон, перешкода, функція й діалог. Являє обгрунтування того, що перші три рівні не потребують існування індивідуального "Я". Перші три рівні залишають екзистенціальне "Я" непотрібним і тому незатребуваним. Філософія діалогу з Іншим ставить не менше питання про умови можливості метафізичного континууму в онтології, і в свою чергу, пропонує прийняття філософської посилки про Бога як простору суб’єктності в діалозі "Я-Ти". Висновки. Філософське осмислення комунікації двох екзистенціальних "Я", затребуваних в спілкуванні, можливе тільки в рамках релігійного дискурсу. Феноменальна свідомість може увійти в спілкування 3 конкретною іншою феноменальною свідомістю тільки тоді, коли між ними пролягає метафізичний простір, що допускає можливість комунікації такого рівня. Матеріалістична обумовленість еволюційними потребами людської природи у всіх мислимих їі видах виробляє редукцію комунікативного запиту, яка унеможливлює взаємне сприйняття двох "Я". У даній психофізіологічній антропологічній моделі відсутній простір можливості діалогу особистостей.

Ключові слова: "Я"; особистість; комунікація; світогляд; метафізика; Інший; еволюціонізм

\section{В. Н. РУБСКИЙ ${ }^{*}$}

$1^{1 *}$ Одесский национальный морской университет (Одесса, Украина), эл. почта pavv@te.net.ua, ORCID 0000-0003-3225-8287

\section{УРОВНИ КОММУНИКАЦИИ ЛИЧНОСТИ}

Цель. В статье рассмотрена проблема взаимовосприятия личностей, что предполагает анализ антропологических предпосылок исследования межличностной коммуникации. В работе подчёркнута необходимость выявить гносеологическую лакуну возможности и востребованности познания чужого "Я". А также указать на имплицитные метафизические установки, универсальные для многих мировоззрений, которые имплицитно включены в теорию общения личностей. Теоретический базис. Автор исходит из логических следствий эволюционной посылки в антропологии. Сопоставляет психофизические цели и задачи межличностной коммуникации с её идеологической теорией, отслеживает невозможность реализации заявленного в сознании уровня коммуникации. В качестве противоположной эволюционной посылке автор приводит постулаты "философии диалога" Ф. Розенцвейга, Ф. Эбнера, М. Бубера и др. Соотношение этих философских позиций выявляет несостоятельность материалистической редукции в антропологии. Научная новизна. Автор выделяет четыре уровня коммуникации: фон, препятствие, функция и диалог. Представляет обоснования того, что первые три уровня не нуждаются в существовании индивидуального "Я". Первые три уровня оставляют экзистенциальное "Я" не необходимым и потому невостребованным. Философия диалога с Другим ставит не меньший вопрос об условиях возможности метафизического континуума в онтологии, и в свою очередь, предлагает принятие философской посылки о Боге как пространстве субъектности в диалоге "Я-Ты". Выводы. Философское осмысление коммуникации двух экзистенциальных "Я", востребованных в общении, возможно только в рамках религиозного дискурса. Феноменальное сознание может войти в общение с конкретным другим феноменальным сознанием только тогда, когда между ними пролегает метафизическое пространство, допускающее возможность коммуникации такого уровня. Материалистическая обусловленность эволюционными потребностями природы человека во всех мыслимых её видах производит редукцию коммуникативного запроса, которая делает невозможным взаимное восприятие двух "Я". В данной психофизиологической антропологической модели отсутствует пространство возможности диалога личностей.

Ключевые слова: "Я"; личность; коммуникация; мировоззрение; метафизика; Другой; эволюционизм

Received: 08.12.2018

Accepted: 14.11.2019 